\title{
Thailand's Cause Lawyers and Twenty-First- Century Military Coups: Nation, Identity, and Conflicting Visions of the Rule of Law
}

\author{
Frank MUNGER*
}

Professor of Law, New York Law School, New York, USA

\begin{abstract}
Conflict among Thailand's legal advocates for popular causes over the legitimacy of Thailand's two twenty-first-century coups raises questions about the meaning of the rule of law. The general perception of inexorable globalization of an international interpretation of the rule of law and of cause lawyers as one of its important vectors runs counter to the experience of developing societies where rule of law is being adapted to the meaning of nation and individual identities informing everyday lives and the relationship between a society and its government. This essay uses career narratives of Thai cause lawyers to illustrate this point by examining sources of the rule of law's meaning, including experiences shared by each generation of cause lawyers and communities of practice shaping individual careers and identities. Their career narratives suggest the importance of continuing relationships with social movement leaders on beliefs about Thailand's readiness for democracy and meaning of a rule of law.
\end{abstract}

Keywords: Thailand, rule of law, lawyers, social movements, military coup

\section{CAUSE LAWYERS AND THE RULE OF LAW}

During nearly three decades under authoritarian and semi-democratic governments before Thailand's liberal constitutional reform in 1997, a small group of lawyers for social causes exploited openings for incremental advancement of law's authority to bring about change. Leaders of a critical popular constituency for constitutional reform in the 1990s, the lawyers used their influence to educate and mobilize ordinary Thai historically excluded from elite politics of the state. The People's Constitution adopted a Bill of Rights, created constitutional and administrative courts, and established full democracy, meeting the expectations of the international community for a modern rule of law. The lawyers joined together as members of the Human Rights Committee of the Lawyers Council of Thailand ${ }^{1}$ to put the new constitutional provisions to use.

\footnotetext{
* Professor of Law, New York Law School. I could not have completed the research required without the dedicated support I received from my Bangkok-based research assistants, Worrawan Jirathanapiwat, Peerawich Thoviriyavej, and Vorapitchaya Rabiablok. This research has been made possible through the generous support from the Law School Admissions Council and New York Law School. Correspondence to Frank Munger, New York Law School, 185 West Broadway, New York, NY 10013, USA. E-mail address: fmunger@nyls.edu.

1. The Lawyers Council of Thailand is the practitioners' Bar association. Chartered in 1985 to license practitioners and provide legal assistance, the Lawyer's Council is less prestigious and influential than the Thai Bar Association, which is dominated by judges and prosecutors who are bureaucrats with relatively high status.
} 
While the Human Rights Committee was still gathering momentum, political conditions rapidly changed. Driven by conflict between groups supporting or opposing the growing influence of elected prime minister, billionaire Thaksin Shinawatra, redshirt (pro-Thaksin) and yellowshirt (anti-Thaksin) protesters filled the streets, sometimes accompanied by violent conflict, bringing government to a standstill. Political impasse opened the door to Thailand's long history of military coups. After abandoning politics in the 1990s, the military has stepped in twice, in 2006 and 2014, ending elected redshirt governments and setting aside constitutions duly enacted by Parliament.

Unexpectedly, the military's return divided the lawyers who had been advocates for rights and accountability under law, not only over political colour, but over the legitimacy of the two military coups. Thailand's first exposure to mass party politics, followed by the rapid rise of a powerful and autocratic prime minister, triggered their political disarray and exposed deep disagreement about the military's extra-constitutional authority. The coups might easily be dismissed as a familiar failure of liberal government in a Global South state, backsliding on the path to modern democracy, or evidence of traditional elites reluctant to yield power, but unexpected conflict among the most committed advocates for the rule of law shows that, in Thailand, and perhaps elsewhere, there is a more complex story about constitutional reform, the role of law in social change, and the meaning of the rule of law.

This article addresses a question emerging from growing interest in the influence of international rule of law ideals and the special interest of scholars in lawyers who deploy law to benefit politically weak or socially marginal causes. "Cause lawyers"-lawyers who "practice with a vision of the good society", —are increasingly visible across the Global South. Even when they have been required to adapt their strategies to legal institutions quite different from those in stable democracies of the Global North, lawyers for social causes are typically understood as advocates for the particular rule of law inspired by Western ideals for law and human rights and promoted through encouragement and pressure by governments, international organizations, and a wide array of foundations and non-governmental organizations (NGOs) who follow in their wake. ${ }^{3}$ Scholars are drawn not only by interest in differences between the careers and strategies of these lawyers and more conventional practitioners, but also by the lawyers' aspirations. Numerous case studies describe the conditions that influence the emergence of legal advocates, the causes they represent, and strategic adaptations or "translations" of international human rights made necessary by local institutions and a local cause, but few focus on the lawyers' perceptions of law. ${ }^{4}$ Few have asked, notwithstanding the influence of the contemporary international discourse, what rule of law are cause lawyers pursuing.

The rule of law is fundamentally about the relationships between a society and its government and among its citizens. Conflict over the rule of law arises not only between adversaries competing for power, but also among allies (in principle) in struggles for social change, reflecting different interpretations of relationships that bind a society together as a nation. We have long abandoned the idea that law is an autonomous influence on social life. Law's terms and rules have no meaning without a context in which experience may be applied to give them meaning. Max Weber noted that it is inherently the function of a lawyer

2. Sarat \& Scheingold (1998), p. 3.

3. Sarat \& Scheingold (2004), p. 137. Contrast Hilbink (2004).

4. Hilbink, ibid., pp. 673-5. 
(or any advocate employing rules) to perform a translation between everyday experience and abstract rule, ensuring in the process that every formal rule has meaning informed by experience and by the complexities of lived relationships. ${ }^{5}$ In turn, law, having become meaningful in this way, elicits support for relationships, individual identities, and the allocation of power. Law, as anthropologist Clifford Geertz has suggested, is one of society's ways of "imagining the real.",

Drawing on interviews and observations gathered during eight years of fieldwork between 2006 and 2014, this article examines the influence of past history and personal experience on present understandings of "rule of law" among Thailand's cause lawyers. Differences among them exist, in part, because of different ways in which they "imagine" the relationships upon which authority ought to be is based. While many scholars view cause lawyers in general as importers of an international rule of law discourse, in fact, few Thai cause lawyers have had direct contact with this discourse. Indeed, most of them speak only Thai and do not use global communication such as the Internet. Their relative isolation makes it all the more clear that they have been local actors whose vision of a rule of law has been shaped largely by local experience and suited to the causes they have served. In turn, their interpretations draw on frameworks closer at hand, some derived from international sources by indirect paths, but also others that have taken hold through continuing relationships. As social and political changes create new contexts for their work, ideas about the roles of citizens and rulers have changed in parallel with their changing role and identity as a cause lawyer.

Career narratives reveal the impact of continuing relationships in overlapping networks on interpretations of experience. These relationships are found in families, university mentors, communities of practice, and the wider mutually supporting group of activist lawyers. Over the length of a career, the lawyer's investment in choices about whom to help and how to proceed has consequences. An evolving narrative of identity about who the advocate is and where the advocate belongs in the social and political world has implications for a vision of the nation and its rule of law, connecting cause work to law and to valued outcomes.

In the analysis which follows, I use the lawyers' career narratives to describe how they imagine law's possibilities and relationship to political power. Multiple generations of lawyers are represented, each coming of age as practitioners under profoundly different political conditions. I look first at changes in the subtle influence of Thailand's "civic religion," a carefully constructed elite discourse about the identities of citizens and rulers of the nation rooted in the historical relationship between the people and their revered monarch. Second, I consider the transformative effects of the 16 October 1973 student-led uprising that marked a turning point in modern Thai history, when struggles from below increasingly influenced national politics. Lawyers in the so-called October Generation formed overlapping, self-sustaining communities of practice that mentored subsequent generations. Over the course of careers and subsequent generations, different communities of practice have exposed practitioners to profoundly different experiences and, as a result, professional identities have diverged and different interpretations of the rule of law now divide the community.

5. Weber (1978), p. 757; Stinchcombe (2001).

6. Geertz (1983), p. 175. 


\section{CAUSE LAWYERS IN THE THAI BUREAUCRATIC STATE}

Lawyers are unlikely activists in Thailand. A court and lawyer-centric understanding of the rule of law ignores much of the unique history of non-colonial states such as Japan, China, and Thailand which has influenced the relationship between law and social change. ${ }^{7}$ The Thai monarchy adopted a bureaucratic state structure in the late nineteenth century to concentrate power and preserve the monarchy's control as well as modernize state administration. Early ministers were powerful subordinates, funding their families as well as their agencies through government revenues. As servants of the king, bureaucrats were remote from ordinary people - a perception that has left its mark on modern Thailand. ${ }^{8}$ Many have judged the rule of law in Thailand from the tumultuous course of its politics, but it should be no surprise that Thailand's dominating state administration has been an important factor in determining the power of law and the relationship between Thai citizens and the state.

Typical of other authoritarian Asian states, the bureaucratic judiciary has been less an independent check on government power than a facilitator of executive polices. Until 1997, Thailand lacked altogether a system of administrative courts. ${ }^{9}$ Civil servants are not given to displeasing superiors, and legal training consistent with the civil law origins of much of Thailand's civil jurisprudence emphasizes rote statutory construction rather than independent consideration of legal policy. ${ }^{10}$ The dominant position of bureaucrats coupled with a weak, conservative judiciary has greatly narrowed the space for lawyers to use law for social change. In contrast to US counterparts, the legal profession has limited formal institutional leverage to broker its power. The upper levels of the profession do not find it advantageous to invest in public interest work and rarely support the work of more activist lawyers.

The judiciary's predisposition to subordinate the interpretation of law to the state's will has been long reinforced by the careful cultivation of the Thai monarch as a unifying symbol. The absolute monarchy ended in 1932, but the monarchy has remained central to the social consciousness of most Thai. Anticipating challenges to the monarchy's legitimacy from modernization and eventual democratization, King Vajiravudh (Rama VI 1910-25), third in a line of modernizing monarchs, promulgated an ideology of the state built upon Siamese traditions and modern democratic ideals. ${ }^{11}$ Vajiravudh's influential formulation of a "civic religion" with deep roots in Siam's history embodied his understanding of the spiritual and moral fabric of modern Thailand's communities and citizens and the monarch's importance as caretaker of the people. The 1932 coup leaders who overthrew Vajiravudh's successor, far from breaking with the principles of his "civic religion"-Nation, Religion, Monarchyembraced its terms to legitimate their government, adding constitutionalism as the

7. Frank Upham (2006) has argued that the individual rights, judicial enforcement, and lawyer-driven model of the rule of law promoted by the so-called Washington Consensus is an "orthodoxy" not shared by most of the rest of the world.

8. Competitive relationships among ministries as well as their insularity and clientelistic internal structure have had long-lasting effects, even as administrators have become more professionally competent. Muscat (1994); Ockey (2004).

9. Although the Thai Council of State received petitions of complaint about government wrongdoing, no juridical culture supported effective supervision of government and the Council made no effort to encourage, much less sponsor, advocacy for rights.

10. Changes in role of law that might have legitimated law's independence from the state were long discouraged not only by the self-contained bureaucracy, but also by the influence of an imported legal ideology, freed from the influence of European natural law, which placed law at the service of the state rather than above it. Lev (2000); Connors (2011).

11. Reynolds (1978). 
embodiment of its democratic elements. Ministries of education, culture, development, and others continue to inculcate reverence for the monarchy and civic religion, reinforcing their presence in the lives of every Thai. The legitimacy of every regime since 1932 has depended upon approval of the monarch and deference to the civic religion. ${ }^{12}$

Since 1973, Thailand's rulers have continued to invoke the elements of this ideology to legitimate their power to modernize the government and economy (indeed, they have found it essential to do so) while continuing to postpone full democracy. ${ }^{13}$ Michael Kelly Connor describes how Thailand's rulers modernized its authority by interweaving development theory of the 1960s and 1970s, imported by Thai academics trained abroad and by foreign advisers. The theory validated strong state leadership and postponement of full popular democracy in order to facilitate rapid development of state infrastructure and a free market economy. Orthodox development theory has moved on, but many of Thailand's ruling elites have not. Influential "liberal royalists" and "democratic conservatives" resist fully embracing popular democracy while using the theory's contemporary themes of participatory development and community empowerment to "liberalize" government by "linking downward to multiple independently organized communities rather than through the bureaucracy, but not to popular will." 14 The result, Connors argues, has been that, for many elite, "liberalism" has meant enlightened capitalism rather than popular democracy. ${ }^{15}$ The rising influence of powerful economic actors and increasing political consciousness of ordinary Thai have triggered conflict among elite factions about reforming the power of the state. ${ }^{16}$ But the most influential elites, Connors concludes, as well as "new [post-constitutional] programmes of civic education by non-state activists, educators, and academics" continue to support the authority of the civic religion to legitimate unelected elite management of political participation by new popular constituencies.

The continuing influence of the civic religion has two important implications for cause lawyers' interpretations of the rule of law. By 1997, liberal intellectuals and social movement leaders were ready to entrust the political future to the decisions of official and politicians subject to constitutional prescriptions and the will of an electorate. Influential royalist reformers brushed this view aside as a profound break with Thailand's traditions, especially the extra-constitutional authority of the monarchy, and, in any event, grassroots groups and their allies lacked sufficient power to drive constitutional reform on their own. ${ }^{17}$ Royalists chaired the constitutional drafting committee and did much of the actual drafting. While the Constitution's Bill of Rights, independent courts, and electoral democracy fulfilled the West's vision of liberal democracy, the drafting committee preserved language in earlier constitutions describing Thailand as a democracy "with the King as head of state," linking national identity and the legitimacy of government to the moral authority of the monarchy. Far from rejecting Nation-Religion-Monarchy, these framers intended to establish the civic religion in the language of the Constitution—constitutionalizing it. ${ }^{18}$ The "original meaning"

12. Ibid.; McDorman (1998); Connors (2008).

13. Connors (2001).

14. Ibid., p. 185.

15. Ibid., pp. 188-9.

16. Naruemon \& McCargo (2011).

17. Connors, supra note 13 , pp. 184-5.

18. Ibid. 
of elite drafters continues to resonate widely, but it is contested by the interpretations of constituencies with a different vision of the 1997 political settlement. ${ }^{19}$

Second, NGOs, social movements, and community-based projects for reform were profoundly influenced by the same "democratic conservatism" that dominated the drafting committee. Throughout the 1980s and 1990s, cause lawyers' projects for social change were created within the political space left by semi-democratic government, and some were created through collaboration or sponsorship of elites within government. These collaborations were made attractive not only by the absence of political alternatives, but also by the presence of an increasingly influential middle class that valued stable development and "just capitalism" but viewed political conflict with concern. ${ }^{20}$ Projects for social change from the top down flourished under the sponsorship of "cause bureaucrats," some in the form of welfare-oriented projects with foreign sponsorship, such as prevention of human trafficking and migrant protection, while others created mechanisms of mediation between levels of government in lieu of true decentralization to facilitate particular forms of development.

\section{3. "OCTOBER GENERATION" ACTIVISM}

The 16 October 1973 student uprising that toppled a military dictator, General Thanom Kittikhachon, and unleashed three years of turbulent democracy has been long remembered by the students and others who participated as a moment of shared expectation and a reminder of the moral value of constitutionalism and political liberalization. The moment ended with a brutal crackdown on 6 October 1976 that slaughtered students, led to arrest and trial for many more, and forced hundreds of individuals to seek sanctuary with communist cadres on Thailand's borders. The restoration of General Thanom to power had lessons of its own for Thai social change advocates about the largely undiminished strength of the military, its allies, and the institutions they supported. Nevertheless, the landscape had changed. After 1973, economic growth and social change mobilized new challengers to Thailand's elite and the entrenched bureaucratic polity bringing more resources and creating more political space for activism. The uprising's legacy lay not only in its powerful example of successful non-elite participation in a political system historically dominated by elite insiders, but also in continuing efforts by members of the October Generation to bring about social change that have profoundly influenced the actions and perspectives of later generations of activists.

October Generation graduates differed from their traditional Thai families. For many, their experiences at university and accompanying the uprising were transformative, providing evidence of widespread inequity and oppression in their society and government and creating a new understanding of nation not shared with their parents. Thammasat University, in Bangkok, became the centre of student radicalism. By the late 1960s, its accomplished liberal, Western-educated faculty were encouraging students to visit Thailand's rural areas and slums - visits that revealed widespread poverty and inadequate government programmes as well as pervasive oppression and corruption. The first NGOs were created to undertake projects assisting long-neglected communities-projects which became models for

19. Albritton \& Bureekul (2007).

20. Connors, supra note 13, pp. 217-18. 
continuing "Thai-style" NGOs and activism. ${ }^{21}$ Many 1970s law graduates began careers with ideals strongly influenced by what they saw and did during these visits, the successful uprising, three years of vibrant democracy, and the crushing return of the military in 1976.

The depth of the students' commitment to change cannot be judged by the demands of the protesters or escalating confrontations with police leading up to the departure of Thanom. The student protesters demanded democracy and a Constitution while carrying banners with pictures of the king and queen and likenesses of the Buddha. Frank Reynolds describes their choice of symbols as skilled diplomacy, drawing on the symbolic elements of the civic religion. ${ }^{22}$ The common ground among students and their public audience, as the leaders knew well, was dislike of Thanom and a desire for accountability. Political consciousness among students themselves varied greatly. The king became the crucial factor in the student's victory by openly disapproving of Thanom, protecting the students, and acquiescing in student demands for a democratic government and a Constitution ratified by the people. Student demands were less clear about the extra-constitutional authority of the monarchy or of the military acting with the king's approval. Thailand first, revolutionary Constitution, in 1932, had made clear that the monarchy was to continue under the law, not above it. Clarification of this and other implications for the rule of law after adoption of the new Constitution in 1974 remained central to future constitutional struggle.

During the period of democracy which followed the uprising, while activist law graduates and lawyers readily connected with advocates for social causes, established new projects for reform, and recruited and mentored new generations, their projects for reform have similarly ambiguous implications for the meaning of the rule of law. From one point of view, these projects acquiesced to the existing rule of law under a hegemonic and largely unaccountable state. For example, the dependence of "Thai-style" NGOs on government partnership can be construed as cooptation rather than reform. Not only did these NGOs lack the power to undertake fundamental reform but, arguably, they did little to make a lasting change in the ideology which made bureaucrats accountable to superiors but not to the people they served.

In law firms which recruited October Generation lawyers, a few were led by practitioners with an elite lineage who converted their protected status into legitimacy of law for social causes. ${ }^{23}$ A few non-elite activist practitioners, who had sometimes volunteered at great risk to take the most controversial cases, gained visibility and charisma after the uprising. Like "Thai-style" NGOs, these firms lacked power to change the rule of law because institutions that defined their roles offered so little leverage to alter fundamental power relationships. ${ }^{24}$ The law graduates who became legal advisers to social movements can be viewed as classic depoliticization of a participatory movement by subordinating popular goals for change to strategies controlled by lawyers. $^{25}$

The social class of student activists makes it easy to conclude that their visits to the countryside and work for projects assisting the residents of rural villages or urban slums, and

21. See Munger (2015).

22. Reynolds, supra note 11.

23. An example is Marut Bunnag, a 1960s Thammasat graduate, members of whose family had served as advisers to Thai monarchs going back to the nineteenth century and before. Marut aided protesting farmers in 1976, represented those accused of high crimes after 1976, and as an MP-proposed constitutional reform in the 1990s.

24. This argument is well established in critical commentary. See Sarat \& Scheingold (2006).

25. See ibid. 
later their establishment of "Thai-style" NGOs, reinforced paternalism at the heart of national identity embraced by the vast majority of Thailand's citizens. Yet, students had taught, built schools and clinics, and advised communities in order to increase their capacity for self-governance. Community development and self-determination were an early theme of the ideology of some NGOs and aligned with a progressive international movement in Global South societies for community empowerment. ${ }^{26}$ Students were exposed to more radical influences as well. Marxism was widely discussed, if not well understood, and a model of Asian nationalism and successful communist revolution was near at hand, namely China. Thammasat Professor Sulak Siviraksa, although not a communist himself, named his foundation supporting critical exchange about Thai society and projects for social reform after a former student communist killed by the military while assisting Thai villagers. In 1976, the Komol Khemtong Foundation, the starting point for the careers of October Generation founders of important "Thai-style" NGOs, became one of the military's first targets.

The violent return of the military in 1976 left hundreds of students dead and many more in jail. Leaders were tried for treason. Years later, one of the leaders described himself and others as trauma victims, still carrying injuries from that moment. ${ }^{27}$ For some, rumours that the king had supported the lethal crackdown led to an epistemic breach in national identity and rejection of the "civic religion," sowing seeds of opposition to the monarchy. ${ }^{28}$ Yet, after fleeing to the jungle in 1976, most returned. Those who sought the protection of the communist cadres were among the most dedicated activists of their generation, but few became communists, revolutionaries, or political radicals. Instead, they returned to seek peaceful change rather than a radical break with Thailand's past.

An alternative interpretation characterizes the lawyers' efforts to deploy the law as important acts of resistance and political change in the rule of law. Traditionally, law and the courts, like Thailand's constitutions, were a resource for the exercise of power by the ruling elite, seldom used as such by ordinary Thai and even less likely to be employed to resist the powerful by those who lived in villages outside of Bangkok. ${ }^{29}$ Describing litigation to enforce the terms of the Land Tenure Act brought by a lawyer for the Northern Farmers Federation in 1974, Tyrrell Haberkorn suggests that, in Thailand, making law a weapon of the weak was itself a revolutionary act. ${ }^{30}$ Using the courts to check the power of land owners and government officials undeniably democratized the rule of law by requiring judges to apply the same strict statutory construction to compliance by landlords or government officials that justified compliance by tenants, farmers, and labourers. Even Thai-style NGOs' use of ministerial regulations or government policies to direct and discipline lower officials who ignored duties or abused their power had the similar effect of putting law above the will of government officials. ${ }^{31}$ In 1973, the demand for a Constitution was already well

26. See Munger (2014), pp. 5-6.

27. Interview, 11 December 2015, Lawyer B (name withheld).

28. Ibid.

29. See Munger, supra note 26, pp. 38-9.

30. Haberkorn (2011), pp. 20-2. As E.P. Thompson (1976) concluded concerning the occasional prosecution and conviction of the elite under the infamous Black Act, the state, having invested itself in law, occasionally had to take it seriously.

31. See Munger (2015). 
established in the "civic religion," but a demand for a Constitution truly from below was without precedent. A new vision of the rule of law was introduced, if not fully realized or universally appreciated.

\section{DIFFERENT CAREERS-DIFFERENT DISCOURSES ABOUT LAW}

Ideologies may serve as rallying cries among activist allies or an invitation to new recruits but, in practice, among lawyers for social causes, ideals acquire meaning in context. Lawyers choose different ways to bring about change. Working relationships with colleagues or collaborators and those they want to benefit influence their perceptions of the alternatives and the choices they make among different methods for deploying law. Continuing relationships become long-term commitments to particular goals and the relative emphasis on formal legal and substantive political change. ${ }^{32} \mathrm{~A}$ vision of change may inspire a lawyer's career but must be reconciled with conditions that make work possible and change real. In this section and the next, the influence of political institutions, national ideology, and communities of practice is traced through the diverging careers of lawyer activists whose careers crossed paths in a single, but important, NGO, the Union for Civil Liberties (UCL). This section describes the NGO and its evolution, and the next section examines the lawyers' responses to the military coups.

The vast majority of October Generations law students who became activists came from poor, rural communities. A number explained that they chose to study law because of a remembered injustice to their families, but often unspoken were the aspirations of their families for upward mobility and a child in a secure, well-paying government position. As student activists, they were exposed to shocking realities of their society, the aspirations for change shared by their mentors and peers, and new frameworks for interpreting what they were experiencing. More than the influence of any theory, they had won a new Constitution and found exciting ways to use their training to bring about change. In 1976, the brutal crackdown reminded them how little had changed in spite of their efforts. When the military government moderated its repression, followed by amnesty in 1980, their careers as activists began again, choosing to act within the political spaces permitted by semi-democratic civilian governments and under watchful military oversight.

Two broadly defined strategies for activists emerged, each requiring consequential commitments. First, networks of personal influence which tied the October Generation to sympathetic government collaborators linked foreign funders, NGOs, and officials through sometimes contentious, sometimes collaborative relationships. These relationships became the operating structure for "Thai-style NGOs," sponsored by reformists within government and liberal royalists. Their continuing presence in the twenty-first century demonstrates the viability of liberal royalism and paternalism at the heart of the "civic religion." 33 To capture the support which some popular sectors are now capable of providing, some Thai-style NGOs have shifted to media and broad-based fund-raising strategies, becoming true lobbies for constituencies and at the same time linked more closely to parliamentary politics. ${ }^{34}$

\footnotetext{
32. Hilbink, supra note 3.

33. Munger, supra note 21.

34. Munger, supra note 26.
} 
Second, social movement mobilization provided an alternative to government collaboration and foreign sponsorship. Driven by social and economic development that brought new groups into contention with government and business, this alternative grew steadily in importance. ${ }^{35}$

UCL was established shortly after the 1973 uprising by university intellectuals and middle-class reformers to promote human rights. Applying Western theories of political socialization, founders Saneh Chamarik, Professor of Political Science at Thammasat University, and Kotom Arya, Professor of Electrical Engineering at Chulalongkorn University, proposed to create a powerful public discourse of human rights. ${ }^{36}$ Both had had extensive exposure to human rights and political theory abroad, Saneh as a trained English Barrister and Kotom as a student in Paris during the 1968 protests. UCL's staff quickly perceived a profound mismatch between the goal of political socialization and the rudimentary knowledge of rights and politics possessed by most Thai. The NGO soon focused on more limited goals through educational outreach to specific groups viewed as ready to benefit from carefully tailored knowledge of their rights and through legal assistance to mobilize politically aware groups, such as labour unions or farmers defending access to land.

UCL became a desirable site for training and mentoring and, over time, an influential crossroads for lawyers and leaders of other NGOs. The NGO's support for mobilized groups of workers, communities, and protesters made it an early target of military suppression in 1976. After 1976, Kotom created a second NGO to carry on the work of establishing human rights under cover of promoting religion, the Coordinating Group for Religion and Society (CGRS). CGRS used its religious mission to enter prisons to monitor treatment of prisoners, torture, and extra-judicial killings. UCL resumed its work in the 1980s under the watchful eye of the military. In 1985, UCL's October Generation director, attorney Somchai Homla-or, who fled to the jungle in 1976, was forced to flee a second time after alerting Amnesty International to the military's human rights violations in refugee camps along Thailand's border.

Although continuing to conduct educational projects and provide legal assistance for popular groups, UCL's more important role has been establishing the language of rights-a discourse shared across a wide range of NGO and community organizations whose leaders served on its board. In 1973, human rights was a new concept in Thailand. Rejected by some student leaders in 1973 as Western and conservative, human rights resonated with NGO and social movement leaders in the 1980s, not only attracting foreign funders, but also providing people's sector organizations with a shared discourse about mission. ${ }^{37}$

During the late 1970s and 1980s, other NGOs were rapidly adapting to an evolving social context. Thailand's extraordinary economic success generated familiar inequities. A new generation of NGOs responded to farmers, forest communities, and fishing villages whose wellbeing and livelihoods lay in the path of government-sponsored development projects.

\footnotetext{
35. Entering directly into law practice was a satisfactory means to earn a living, but firms depended on clients, and here the choices were limited. Defending the persecuted has been the activist lawyer's bread and butter, but becoming involved in projects for change by advising or staffing NGOs or working community-based organizations able to invest resources in pursuit of change are the principal alternatives.

36. Suwatee (1989) p. 116.

37. Connors, supra note 13, p. 216. MA thesis-NGOs on board a who's who.
} 
Under the semi-democratic governments of the 1980s, movement leaders were cautious. In 1987, the Thai Volunteer Service's Annual Directory of NGOs explained that NGOs had learned from the "unhappy experience of ... the 1970s." ${ }^{38}$ NGOs had decided to reject conflict or violence as a way of solving problems, and believed in "carrying out small-scale peaceful, practical activities" as part of "a long, peaceful process of change in consciousness." 39 As a network of developmental NGOs emerged, supported by mobilized communities and new sources of funding, government moved toward reducing conflict through negotiation and co-operation which by-passed an unrepresentative and unresponsive Parliament. ${ }^{40}$ To co-ordinate and strengthen their position, in 1985, the NGOs formed an independent peak organization, NGO-CORD, marking the beginning of a stronger NGO movement capable of negotiating local development and supporting constitutional reform. ${ }^{41}$

Unlike Thailand's development-related NGOs, which have flourished, UCL's broader and more abstract mission to change popular consciousness and public policy has seen its external support wither and its survival reduced to dependence on other NGOs. ${ }^{42}$ Projects concerned with side effects of capitalism have survived by connecting community constituents with officials ready to improve government policies, by-passing unrepresentative Parliaments by negotiating directly with ministries and liberal politicians. UCL's mission to bring about fundamental change in the rule of law had potentially far more radical implications, but UCL attracted no government partners and lacked both public visibility and understanding. UCL's original mission remained an idea who's time had yet to come.

Notwithstanding UCL's lack of popular support and declining funding, the NGO gave its lawyers important social capital. UCL's staff members were among the first to develop strategies to make rights meaningful to ordinary Thai, through public education, campaigns to support popular mobilization, and litigation. Although UCL's small staff has limited capacity to counsel groups shunned by the private Bar, the diaspora of lawyers who worked for UCL and generations mentored by them is very large. Second, UCL helped establish a discourse of human rights and government accountability among cause lawyers and other NGO leaders that continues to unify them.

The recent coups have forced the lawyers who share, directly or indirectly, UCL's training and mentoring to think again about Thailand's rule of law. UCL's influence has helped to harmonize working relationships and collaborations, but there are sharp differences among its alumni reflecting deeper layers of identity and the constitutive effects of diverging career choices. After working with UCL, lawyers have pursued paths which embed some in close relationships with leaders and members of community organizations and others in more conventional sites of practice-private firms supported by private clients or roles in

38. Thai Volunteer Service, Directory of Non-Governmental Development Organizations in Thailand, unabridged version, Bangkok: TVS, 1987: 10. Quoted in Connors, ibid., pp. 217-18.

39. Connors argues that NGOs also retained their critique of capitalism, choosing strategies based on partnership with middle-class interests while not losing sight of class difference. Ibid., pp. 2199-220.

40. Connors, supra note 13, p. 216. Baker \& Phongpaichit (2009), p. 256.

41. Connors, ibid., p. 161.

42. UCL itself lacked popular support and, by 1992, when many international agencies no longer considered Thailand poor, its resources dwindled and its branch offices closed. By 2006, the Bangkok staff had been reduced to four and, by 2014, UCL existed in name only, a branch of a French NGO which funded UCL's board and its capacity to serve as the policy voice of progressive NGOs. Interview with Chalit Meesit, 13 December 2012. UCL still conducts training and education programmes, but mostly serves as a policy advocate on behalf of the NGO community. Interview Pairoj Pholphet, 19 December 2006. 
government or universities. Critical points of difference between their views of political authority, democracy, and role of law may be related, in part, to different communities of practice.

\section{MANY WAYS OF SEEING RED}

When democracy soured under Prime Minister Thaksin's autocratic rule from 2000 to 2006, Thailand's politics entered a new era of turmoil. Lawyers who dedicated careers to supporting NGOs and social movements, litigating constitutional principles, and promoting integrity and good governance are divided. Saneh Chamarik, founder of UCL, mentor for many October Generation activists, and influential intellectual behind the 1997 Constitution, sympathized with the 2006 coup. Human rights litigator, Nitithorn Lamluea, mentored at CGRS by co-UCL founder Kotom Arya, became an organizer in the anti-Thaksin movement and believes military rule may be better. Chalit Meesit, long-time UCL labour litigator, organized a firm dedicated to working with social movements whose partners and younger associates are sympathetic to redshirts, and the youngest of whom, Arnon Nampa, openly opposes the legitimacy of the coup governments.

Others in the long-standing network of cause lawyers have yellow or red leanings but have not taken a public stand on the actions of the military junta. Yet their silence speaks. Prudence may counsel discretion in speaking publically and, as I discuss below, for many, little has changed. For a few lawyers, deeper conflicts are apparent about the question of legitimacy.

Most puzzling is the silence of Somchai Homla-or, former UCL director, street fighter against two previous military governments, and organizer of the post-1997 committee of cause lawyers to co-ordinate efforts to strengthen constitutional rights, has drawn criticism for his failure to speak out about the legitimacy of the military juntas, his failure align himself with his friends in the red cause, and his support for retention of the lèse majesté law used to silence troublemakers and political opposition. Somchai's silence about the military, in view of his strong opposition to previous military governments, provides an opportunity to explore in detail the influence of identity, national ideology, and career on the meaning and legitimacy of the rule of law.

\subsection{Debating "Genuine Democracy"}

The day after the 2006 coup, Saneh Chamarik, now Chair of the National Human Rights Commission established by the 1997 Constitution, remarked to his university students that "a coup d'Etat was the only remaining way out"43 — a comment destined to go viral. Saneh's validation of the coup shocked those who admired him as founder of UCL, an intellectual who interpreted but also fought for human rights for Thailand, and Chair of an aggressive campaign by the National Human Rights Commission. Interviewed in December 2006, Saneh explained that the coup saved Thailand's potential for popular democracy from "predatory capitalists." As scholar and public intellectual, Saneh rose to prominence by writing about an appropriate meaning for human rights in Thailand, combining Western individual rights and communitarian values. As a close adviser to the 1997 drafting committee, Saneh advocated establishing these values in the Constitution.

43. Cheuachang (2006). 
In 2006, Saneh said that successive constitutions had moved Thailand toward more expansive democracy, pressured by the middle class and capitalists who funded Thailand's growth. Under Thaksin, the ousted prime minister, capitalism became predatory, using vast amounts of money to buy bureaucrats, military, and Parliament. ${ }^{44}$ Saneh rejected democracy and constitutionalism for their own sake, saying the people were being led astray by elites charged with guiding them, especially journalists and squabbling intellectuals.

Saneh's criticism of intellectuals and journalists might have referred to the growing importance of popular media in mobilizing dissent. Reflecting, in part, the rising importance of the media, a small group of Thammasat faculty critical of the coup government and its actions, currently calling themselves Nitirat, ${ }^{45}$ have risen to public prominence. In 2006, they issued a public statement declaring the actions of the coup government contrary to the rule of law. The group and its informal leader, Worachet Pakeerut, speak publically and are popular with the press, ${ }^{46}$ opposing the coup's legal actions, challenging the legitimacy of the 2007 Constitution drafted under the military's supervision, and calling for repeal of the lèse majesté and computer crimes laws that have been increasingly used to suppress political opposition. ${ }^{47}$ Worachet's personal comments about the monarchy have made him a lightning rod for government reprisal. ${ }^{48}$ When Nitirat's scholars hold university seminars, they draw large public audiences, mostly redshirt sympathizers. Although Nitirat's members say they are merely scholars interpreting the law without bias, the group unquestionably plays a political role. Nitirat's rise reflects both the changing landscape of Thai politics as new forms of popular participation fuel political contention and the heightened importance of a discourse of legal and constitutional legitimacy after the 1997 Constitution. $^{49}$

An opposing group of influential academics and intellectuals coalesced in 2012 to support the government's actions, calling itself Siamprachapiwat (unofficially Siam Progress). ${ }^{50}$ Professor of Law Banjerd Singkaneti, spokesperson for Siamprachapiwat, argued that the system of checks and balances under the 1997 (and 2007) constitutions were not strong enough to guarantee true democracy through party competition ${ }^{51}$ because "[c]apitalists, by nature, will monopolize everything." Strong patron client relationships continue to characterize Thai society, he says, facilitating capitalist political monopoly by undermining the independence of each branch of government. He says he no longer believes in that form of government "because democracy under a powerful capitalist cannot be the rule of law." 52 In contrast to Saneh's communitarian theory of democracy, Banjerd's vision of the nation includes an important role for the monarchy. An institution like the monarchy which has

\footnotetext{
44. Ibid.

45. Originally calling themselves the Thailand Law Lecturers, their new name evokes the party which led the 1932 coup. McCargo \& Tanruangporn (2014b).

46. Nitirat's university seminars draw large public audiences. Ibid.

47. Ibid., pp. 7-8.

48. Worachet was arrested shortly after the 2014 coup for allegedly ignoring an order from the military to report for questioning. Prachatai news (2014).

49. McCargo \& Tanruangporn argue that Nitirat brought a "new dimension" to Thai politics by using their authority as scholars rather than academics turned pundits to address partisan issues. See McCargo \& Tanruangporn (2014a), p. 23.

50. Manager online (2012).

51. Ibid. Banjerd characterized Nitirat's rule of law formalism as theory divorced from sociology.

52. Banjerd is a member of a small group of lawyers drafting Thailand's next Constitution under military supervision.
} 
existed so long, he says, is of value to the country during its transition because it maintains the identity of the nation and the legitimacy of its government even after the coup.

Nitirat and Siamprachapiwat have helped define the terrain of conflict between competing visions of the nation and rule of law converting political conflict into constitutional interpretation. An important Constitutional Court decision in 2013 invalidated an amendment by the redshirt government, altering the composition of the Thai senate from a halfelected, half-appointed body to a fully elected body. The amendment would, the Court said, permit a powerful majority to trample the interests of a minority. ${ }^{53}$ Although the Court never named the minority interests at risk, it is suggestive that the 2007 Constitution limited appointment of Senators to university-educated, non-partisan candidates, ensuring, at a minimum, reduced party control and strong middle-class representation. ${ }^{54}$ Banjerd, the Siamprachapiwat spokesperson, considered the decision a recognition of the true meaning of the principle of checks and balances as a safeguard for the balance of power among traditional social classes and the moral centre embodied in the monarchy. ${ }^{55}$

Nitirat's analysis of the Constitution is quite different. ${ }^{56}$ Its spokesperson, Worachet, said that the amendment, if procedurally valid under the 2007 Constitution, was legitimate because it reflected the principle of majority rule and, contrary to the Court's opinion, was not in conflict with the constitutional prescription requiring constitutional interpretation consistent with "the democratic regime of government with the King as Head of State.",57 The Court's own analysis, he said, contravened the principle of democracy. Majority rule permits a minority to voice its views, he said, but it does not mean complying with the minority's demands. ${ }^{58}$

\section{2 “Undermining Thailand's Democracy"}

Cause lawyer Nitithorn Lamluea, mentored in human rights by UCL co-founder and public intellectual Kotom Arya, and prepared for successful business practice by former UCL director, Wasant Panich, ${ }^{59}$ has become a well-known human rights litigator. His litigations on behalf of slum communities fighting eviction in Bangkok and on behalf of the Foundation for Consumers to prevent Thaksin's privatization of the Electrical Generating Authority of Thailand, among others, bring a steady stream of human rights victims and NGOs to his office. He does not maintain a special connection with particular NGOs or social movements, but presents himself as a specialist in defending human rights. He prides himself on having advised both red and yellow protesters about their rights.

Among the lawyers in Somchai's Human Rights Committee network who have given much of their time to social causes, Nitithorn is not alone in opposing Thaksin's party or

53. Decision of the Constitutional Court, 13 November 2013 (in Thai).

54. Constitution of the Kingdom of Thailand (2007), Arts. 115, 116.

55. The Court's decision may also be understood as a reflection of "procedural constitutionalism" envisioned by intellectuals like Saneh and others who placed greater emphasis in 1997 on controlling politicians to maintain political stability than on establishing popular democracy. See Connors, supra note 13.

56. Prachatai news (2013).

57. Constitution of the Kingdom of Thailand (2007), Art. 68.

58. Prachatai, supra note 56.

59. Wasant entered practice in 1976 as an associate of Marut Bunnag, a liberal elite attorney who advanced the cause of constitutional reform in the 1990s. See supra note 17. 
accepting the necessity of the coup, but Nitithorn's views are well defined and his actions have been far more extreme. By 2006, he had become an outspoken leader and organizer of the anti-Thaksin movement, and he has continued to organize and lead protests. Like Saneh, he believes the coup was inevitable and has had a positive outcome. Nitithorn drew the attention of Americans with his threat to seize the US embassy in Bangkok in December 2013. US demands for free elections, he said, were "undermining Thailand's democracy." 60 In February 2014, he helped organize polling station blockades which invalidated the redshirt government's attempt to hold an election.

Like Saneh, Worchet, and Banjerd, Nitithorn's partisan views reflect his interpretation of Thai democracy. Nitithorn says the problem is not the capacity of the people, the misguided press, or irresponsible NGOs, but corrupt politicians, whom he connects to the power of a small number of wealthy families who control Thai politics and prevent fair elections. ${ }^{61}$ Until the problem of corruption is addressed, elections are meaningless. Even a complete restructuring of institutional checks and balances, as the current constitutional drafting committee has attempted to do, is misguided.

US interference with Thai elections went beyond insistence on an empty formality, he argues, but also reflected misperception of the legitimacy of Thai governments. The rule of law is not solely about preventing corrupt politicians from undermining fair elections, but also about the legitimacy of extra-constitutional checks and balances. This implicit Constitution, if not the one expressly written, requires public consultation but not necessarily popular control of government decisions, and a moral standard for government policies. These views are quite consistent with Saneh and Banjerd's understanding of a rule of law which, for now, authorizes governance for rather than by the people.

Public participation is essential, he believes, but good government does not require popular elections. The Thai people will be satisfied if three conditions are met: people are allowed input on government policies, communities control their own resources including taxes, and people have access to justice. The last includes respect for not only legal rights, but also social equity. ${ }^{62}$ Indeed, the military, he thinks may have advantages in accomplishing all three. ${ }^{63}$ By contrast, Thaksin's government was not a true democracy, not only because elections were not transparent, but also because government did not listen to those who disagreed and its policies did not increase equity.

\subsection{The Will of the People}

Arnon Nampa, a 2008 law graduate, is from Thailand's north-east, a red stronghold, and he calls the red movement "his family." 64 He joined Chalit Meesit's law firm because he admired one of Chalit's younger partners, Surachai Trong-ngam, who began his own career working for UCL and other NGOs before joining Chalit. Surachai's skill as an environmental

60. Hookway (2013). Interviewed after these events, he said "we want the U.S. to stop putting pressure to have everything modelled on U.S. democracy ... they should understand that the internal problems in Thailand are different from the states, and solutions will be different, too." 12 December 2014.

61. Ibid.

62. Nitithorn has in mind the failed Puea Thai (redshirt party) rice subsidy programme.

63. Surprising for a human rights lawyer, Nitithorn says that the military's speed is an advantage because cases before the constitutional anti-corruption commission can take two years.

64. Interviewed on 30 June 2009; 26 June 2012; 7 December 2014. 
litigator and dedication to community-based action has drawn support from environmental NGOs and admiring recruits. In 2011, Arnon and a colleague formed a firm in part to earn a better living, though he has had little time for business clients. The partners named their firm ratsadornprasong, Will of the People.

Not satisfied with the meagre assistance to red protesters being provided by the Lawyers Council of Thailand and unhappy with the Council's public defence of the coup government, Arnon and a group of younger lawyers formed the Human Rights Lawyers Association (HRLA) of Thailand. In 2011, the HRLA publically denounced the 2006 coup government and called for repeal of the lèse majesté and computer crimes law. Although Nitirat and the HRLA are not affiliated, Nitirat members serve as expert witnesses in Arnon's computer crimes cases and Arnon talks to them regularly. Ideological parallels suggest Nitirat's influence. Arnon, like Worachet, rejects the view that the Constitution implicitly required maintaining a balance of power between traditional social interests. "Anything that is not channeled through the people's resolution, even if the coup makes our economy prosper ... it's still not democracy," he says. "You have to decide which type of society you want to be in." ${ }^{65}$ Although clear about his political commitments, Arnon says that the law is above politics. Similarly to statements made by Nitirat members that human rights are advanced by strengthening law's political neutrality, Arnon emphasizes that he defends anyone whose human rights have been violated, and he represents some social movements with a distinctly "yellow" membership.

Similarities aside, Arnon's understanding of the relationship between these abstract principles and the adequacy of formal constitutional democracy is nuanced. Arnon says that Thailand's judiciary still does not understand the force of rights established by the 1997 Constitution and strengthened by the 2007 Constitution adopted after the first coup, much less their foundation in human rights. His role as a litigator is to educate judges about the social conditions that make constitutional rights and liberties necessary and legitimate. The lawyers at his mentor's firm spend many hours discussing how to argue for "justice beyond the law" using common-sense examples as illustrations of the purpose behind constitutional protections in order to persuade judges who do not understand human rights. ${ }^{66}$

Further, a lack of comprehension of national politics or knowledge of rights by many who live in rural Thailand complicates the struggle to establish the rule of law and a genuine democracy. Many rural villagers have no concept of the modern nation or their role in democratic politics. ${ }^{67}$ Villagers believe that voting for the headman and the prime minister are the same, exchanging their votes for specific benefits. Once in office, the office-holder is beyond the reach or knowledge of the villagers and of little concern to them. ${ }^{68}$ Arnon says that the communities he represents, including the redshirt protesters who come to Bangkok, are different because they understand their constitutional rights and their own role in a democracy.

Arnon's willingness to acknowledge the risks of entrusting democracy to Thailand's current electoral majority opens the door to a second-level debate about whether Thailand's

65. Saratee (2014).

66. Arnon's view is confirmed by my interviews with high-ranking members of the judiciary. Interview, 1 July 2009, Appellate Division Justice A (name withheld).

67. Interview, 26 June 2012.

68. Arnon's first-hand description confirms Andrew Walker's characterization of these ground rules as a "rural Constitution" accepted by many villagers as a basis for political participation. See Walker (2012). 
political parties are capable of managing democracy and about which rule of law has been legitimated by the will of the people — an issue over which Arnon and intellectuals like Saneh and Banjerd sharply differ, and about which Somchai Homla-or has been unwilling to speak publically.

\subsection{Choosing Sides}

Somchai's chairmanship of the Human Rights Committee of the Lawyers Council of Thailand established cause lawyering in a new way by organizing the networks of cause lawyers for more effective collaboration with, as he has put it, "a new generation of advocates dedicated to working with people's movements, respecting their needs and goals, and empowering the people" - a phrase he used often in interviews for this research. ${ }^{69}$ Somchai's own career shows the depth of his commitment to human rights and democracy, but the political crisis and the coup in 2006 presented him with difficult choices. His reputation as a leader among human rights advocates began to erode, say his critics, after allegations of his sympathy for yellow demonstrators in 2006, his failure to speak out against the military breach of the rule of law or its violations of human rights after 2006, and failure to condemn the military as a member of the Truth for Reconciliation Commission of Thailand (TRCT) appointed by the Democrat government in 2011 to investigate the deaths of nearly a hundred protesters during military crackdown on red demonstrations in 2010. Notwithstanding increasing numbers of lèse majesté cases brought against activists and journalists who criticize the government, he has refused to join Nitirat's call for repeal, suggesting as recently as 2012 at a seminar at Thammasat University that the crime of lèse majesté has a proper purpose, and its use should be limited but the law need not be repealed. ${ }^{70}$

Reluctant to speak directly, in public or in interviews, about rule of law questions raised by the coup government, Somchai wrote a "Foreword" for a 2008 compilation of case studies of EnLaw's environmental litigation. ${ }^{71}$ Somchai describes the commitment of the new generation of cause lawyers to defending human rights by collaborating with people's movements but also makes veiled reference to the recent crisis of democracy in Thailand, concluding with a warning in which we can hear not only the voice of the twice-arrested, twice-jailed radical but also the veteran advocate's concern about Thaksin's threat to popular democracy in a reference to people who are refusing "to throw off the chains themselves ... while ... walking unimpeded into the same trap." ${ }^{, 2}$ This thinly veiled reference to Thaksin suggests Somchai's affinity with the generation which drafted the 1997 Constitution as a safeguard against political corruption and a guarantee of unimpeded civil society development.

Somchai, like many other members of his generation, views Thaksin's excesses and the apparent failure of popular democracy as another moment of constitutional transition. Popular democracy yielded a tyrant, but nothing impedes the continued collaboration between legal advocates and genuine people's movements. For the October Generation, the military's disruption of constitutionalism is a familiar intervention. Where the military is not

\footnotetext{
69. Interviewed on 31 December 2006; 18 June 2007; 9 December 2014.

70. The Nation (2012).

71. Homla-or (2008).

72. Ibid., pp. 4-5.
} 
directly involved, little has changed, including Somchai's faith in the progress being made by environmental NGOs and peaceful community organizations like those represented by Chalit's firm and its protégés.

If this interpretation is correct, Somchai's view has a narrow margin of common ground with the liberal royalists who drafted the 1997 Constitution and Professor Banjerd, who will play an important part in drafting the next version, although they are also separated by sharp differences. Banjerd, like Somchai, has worked with NGOs and he supports activists who resist, according to his own characterization, overreaching by capitalists. But Banjerd is a conservative and a monarchist, not an advocate for people's empowerment. Somchai, unlike Banjerd, has viewed defending human rights as a step toward enabling popular democracy. In 2010, as the TRCT began its investigation, Somchai said his objective was to end mutual political distrust that was undermining effective democracy, offering an alternative to military intervention. He has also acknowledged that he feels personally closer to many red movement leaders. ${ }^{73}$ More recently, Somchai has been openly critical of the military's lack of concern for human rights, especially its violent suppression of Muslim communities in Thailand's deeply troubled south. In response, the military has sued Somchai's Cross-Cultural Foundation and Somchai himself as Chair of its board for defamation and libel. ${ }^{74}$ But, while the Foundation has courageously reported on the military's human rights violations in Thailand's southern provinces, neither the Foundation nor Somchai himself has taken a stand on the military's human rights violations elsewhere, much less its apparent disruption of constitutional government.

Somchai's role as leader of a mature and now well-connected community of cause advocates fits seamlessly with his upwardly mobile career. Son of a government official who was also a businessman in Ayutthaya, Somchai's middle-class background helped place him in leadership roles in a generation with strong aspirations for upward mobility promised by widening access to university education and a rapidly expanding economy. Although earlier crises of democracy in Thailand provided opportunities for leadership in political change, his career as spokesperson for human rights in Thailand has brought him recognition as government adviser and member of the Law Reform Commission, and the TRCT. Proximity to government authority may come at a price, however, creating difficult choices when social cause advocacy spills beyond the community level to present a new vision of national authority or rule of law. Somchai's standing with his successful contemporaries is similarly entangled with government and other elites, and his membership on government commissions, well-placed clients, and friendships with peers in mainstream law firms may be a source of dissonance within his identity as a radical.

\section{CONCLUSION: COUPS, CAUSE LAWYERS, AND OTHER SIGNS OF PROGRESS}

Just as Benedict Anderson suggested wryly that rising numbers of murders of candidates in Thailand's brutal 1960s politics demonstrated the value of seats in Parliament, the return of military coups and return to the cycle of rewriting Thailand's Constitution in the twenty-first

73. Interview, 9 December 2014.

74. Asian Human Rights Commission-Urgent Appeals Programme (2014). 
century is perverse evidence of the threat posed to entrenched elites by the recent demands for popular democracy. ${ }^{75}$ At the same time, the varied responses of cause lawyers, who continue to be an important cadre of foot soldiers for change, add complexity by illustrating subtle limits and possibilities underlying a seemingly inevitable transition to a modern rule of law.

Thai scholar Kasian Tejapira described how an emerging Thai communist movement in the 1940s drew on the charisma of Chinese nationalism during World War II to create an indigenous ideal, concluding that " $[\mathrm{t}]$ ranslation thus serves much more than merely an informational function since it transposes concepts, values, and beliefs from one national imagination to the formation of another." 76 Similarly, legal advocates employing the international vocabulary of "rule of law" or "human rights" or new interpretations of domestic law also attempt to create a "national imagination"- a vision of a nation in which the symbolic power of law and rights are distributed in a new way while preserving valued features of the old. Career narratives of Thailand's advocates for social causes bear out Kasian's suggestion that the lawyers' efforts to change society by transforming the rule of law are often linked to an ideological framework, connecting their actual work to the social change they desired.

Self-conscious ideological transformation has been far less important in the evolution of Thai cause lawyers than it was for Thai communists attempting to found a national movement. Experience and commitments made over the length of career, drawing support from the available sources for the legitimacy of law, shaped the identities of lawyers as advocates for change and their understandings of the nation and its rule of law. How exactly have experience, ideology, and change shaped their perceptions of the rule of law? The most important event in the career narratives is the 1973 uprising which marked the point at which struggles from below rather than contention among ruling elites would increasingly drive national politics. Although I have used only a few of the most striking narratives as illustrations, it is apparent that cause lawyers soon became embedded in strategies chosen to work peacefully within spaces created or left open by powerful elites who dominated state power after the mid-twentieth century. Variations in strategy structured the overlapping, networked, but distinctive careers of advocates. New options have opened over time as popular mobilization becomes more persistent, more creative, and closer to the centre of national politics, until at the present times it represents a political force which defies constitutional manipulation designed to suppress or deflect its power.

As I have shown through examination of their career narratives and responses to the recent military coups, the lawyers rarely differ in acceptance of the continuity of law's authorityindeed, quite the opposite. From their perspective, law's authority has grown over time, yet, for many of the lawyers, law's authority seems to have exceptions, and democracy's apparent failure has been revealing, even to them. Somchai Homla-or clearly seems uncomfortable with the logic which commands his silence. Two preliminary conclusions may be drawn about the sources of these otherwise puzzling findings. First, the lawyers' conflicting views are due less to political ideology — a factor frequently advanced to explain differences among American cause lawyers - than to concrete experience, especially experience with popular

75. Anderson (1998).

76. Tejapira (2001), p. 191. 
agency and exercise of power. The reciprocal effects of experience and interpretation on long-term commitments that form an identity are subtle; yet, over time, communities of practice whose lawyers trust popular causes to make decisions about the lawyer's role, and where trust has become part of professional identity, may express greater confidence in popular democracy. As Rachel Kleinfeld concludes, rule of law is fundamentally about the relationship between a society and its rulers. ${ }^{77}$ Surachai, and his protégé Arnon, illustrate the potential effects of a community of practice that validates the people's agency on perceptions of the capacity of Thai people for self-rule.

Second, while constitutionally mandated democratic government has been the subject constitutional controversy, governing continues, raising questions about the meaning of constitutional government and a continuing rule of law. Rule of law remains vital in the branches which have maintained stable administration and its accountability under law, namely all courts but the Constitutional Court. The unquestioned legitimacy of the functioning branches of government reflects a powerful residual rule of law ideology which may have two different sources. It may be argued that elements of Thailand's unique civic religion underlie political and legal consciousness. For some lawyers, Thai government has continuing authority because its legitimacy is independent of the express constitutional formulations in 1997 and 2007. Legitimacy is reinforced, in fact, by the continuing vitality of Thailand's moral centre in an extraconstitutional branch of government, the monarchy. ${ }^{78}$ For other lawyers, democratization of law may be proceeding incrementally, affirming as it does so the identity of cause lawyers as advocates for a more liberal, and globally endorsed, rule of law. The second argument is based on a perception that constitutionalism has thickened, evidenced by the robust "afterlife" of many of the 1997 Constitution's principles. ${ }^{79}$ As part of this process, the constitutionally established courts, with many backward steps to be sure, are arguably asserting a degree of independence, learning a new role as they expand their power. Even the maligned Constitutional Court has shown signs of independence, ${ }^{80}$ while the administrative courts have signalled greater independence from the executive branch, perhaps because of differences in the process of appointing judges or their unambiguous mandate to supervise government.

Daniel Lev concludes his comparison of strikingly different strategies and careers of cause lawyers in Malaysia and Indonesia by identifying their essential similarity, a commitment to the rule of law, and a state which preserves it. ${ }^{81}$ At the beginning of the twenty-first century, Thailand's cause lawyers might be similarly characterized. But Lev well understood that, while this similarity might be true at a high level of abstraction, the unique path of political development in every society has meant that the modern rule of law's pragmatic goals, democratic accountability, and protections for rights have been interpreted in light of experience and other values which give meaning to lives of the intended beneficiaries and in light of pragmatic strategies for reform.

77. Kleinfeld (2012).

78. According to Connors, drafters of the 1997 Constitution attempted give the moral role of monarchy a textual foundation. See also Harding \& Leyland's invaluable interpretation of Thai constitutionalism. They note that the military's assertion of extra-constitutional legitimacy is increasingly constrained by unwritten rules and requires the support of the monarchy. Harding \& Leyland (2011), p. 28.

79. Ginsburg (2009).

80. McCargo (2014).

81. Lev (1998). 


\section{REFERENCES}

Albritton, Robert, \& Thawilwdee Bureekul (2007) "Public Opinion and Political Power: Sources of Support for the Coup in Thailand." 19 Crossroads: An Interdisciplinary Journal of Southeast Asian Studies 20-49.

Anderson, Benedict (1998) "Murder and Progress in Modern Siam," in B. Anderson, ed., The Spectre of Comparisons: Nationalism, Southeast Asia and the World, London: Verso, 139-73.

Asian Human Rights Commission—Urgent Appeals Programme (2014) "Thailand: End Judicial Harassment of Human Rights Defenders," Asian Human Rights Commission, 17 September, online $<$ http://www.humanrights.asia/news/urgent-appeals/AHRC-UAC-133-2014/?searchterm=cross\% 20cultural\%20foundation\%20urgent\%20appeals $>$ (last accessed 8 March 2015).

Baker, Chris, \& Pasuk Phongpaichit (2009) A History of Thailand, 2d edn, Cambridge: Cambridge University Press.

Cheuachang, Muhida (2006) "Special Interview with Saneh Chamarik: Clarifying his Statement 'a Military Coup Is the Only Way Left'," Prachatai, 26 December, in Thai, online < http://www. prachatai.com/print/11064> (last accessed 3 September 2015).

Connors, Michael K. (2001) Democracy and National Identity in Thailand, London: Routledge/Curzon.

Connors, Michael K. (2008) "Article of Faith: The Failure of Royal Liberalism in Thailand." 38 Journal of Contemporary Asia 143-65.

Connors, Michael K. (2011) “Ambivalent about Human Rights: Thai Democracy," in T.W.D. Davis \& B. Gilligan, eds., Human Rights in Asia, Cheltenham, UK: Edward Elgar.

Geertz, Clifford (1983) Local Knowledge, Further Essays in Interpretive Anthropology, New York: Basic Books.

Ginsburg, Tom (2009) "Constitutional Afterlife: The Continuing Impact of Thailand's Post-Political Constitution." 7 International Journal of Constitutional Law 83-105.

Haberkorn, Tyrell (2011) Revolution Interrupted, Madison, WI: Wisconsin University Press.

Harding, Andrew, \& Peter Leyland (2011) The Constitutional System of Thailand, a Contextual Analysis, Oxford: Hart.

Hilbink, Thomas M. (2004) "You Know the Type ...: Categories of Cause Lawyering." 29 Law \& Social Inquiry 657-98.

Homla-or, Somchai (2008) "Foreword," in D. Paisanpanichkul, ed., Environmental Justice: Essays and Interviews about Environmental Lawsuits, Bangkok: EnLaw, in Thai.

Hookway, James (2013) "Thailand's Army Tries on Role of Peacemaker." Wall Street Journal 13 December, online <http://www.wsj.com/articles/SB100014240527023041737045792596641878 17446> (last accessed 9 March 2015).

Kleinfeld, Rachel (2012) Advancing the Rule of Law Abroad: Next Generation Reform, Washington, DC: Carnegie Endowment for International Peace.

Lev, Daniel S. (1998) "Lawyers' Causes in Indonesia and Malaysia," in A. Sarat \& S. Scheingold, eds., Cause Lawyering: Political Commitments and Professional Responsibilities, New York: Oxford University Press, 431-52.

Lev, Daniel S. (2000) Legal Evolution and Political Authority in Indonesia: Selected Essays, Kluwer Law International.

Manager online (2012) "A group of Lecturers Lunched 'Siamprachapiwat' Vowing to Fight the Monopoly of Political Capitalists," Manager Online, in Thai, 13 January, online <http://www. manager.co.th/politics/viewnews.aspx?NewsID=9550000005505> (last accessed 9 March 2015).

McCargo, Duncan (2014) "Competing Notions of Judicialization in Thailand." 36 Journal of Contemporary Asia 417-41.

McCargo, Duncan, \& Peeradej Tanruangporn (2014a) "Branding Dissent: Nitirat, Thailand's Enlightened Jurists," Journal of Contemporary Asia, online <http://dx.doi.org/10.1080/00472336.2015. 1020563> (last accessed 17 June 2015).

McCargo, Duncan, \& Peeradej Tanruangporn (2014b) "Wreck/Conciliation? The Politics of Truth Commissions in Thailand." 14 Journal of East Asian Studies 377-404. 
McDorman, Ted L. (1998) "Constitutional Change and Continuity in Thailand in the Aftermath of the 1991 Coup," in D. Johnston \& G. Ferguson, eds., Asia-Pacific Legal Development, Vancouver: University of British Columbia Press.

Munger, Frank (2014) "Revolution Imagined: Cause Advocacy, Consumer Rights, and the Evolving Role of NGOs in Thailand." 9 Asian Journal of Comparative Law 29-64.

Munger, Frank (2015) "Trafficking in Law: Cause Lawyer, Bureaucratic State and the Rights of Human Trafficking Victims in Thailand." 39 Asian Studies Review 69-87.

Muscat, Robert (1994) Thailand and the United States: Development, Security and Foreign Aid, New York: Columbia University Press.

Naruemon, Thabchumpon, \& Duncan McCargo (2011) "Urbanized Villagers in the 2010 Redshirt Protests: Not Just Poor Farmers?" 51 Asian Survey 993-1018.

Nation, The (2012) “Time 'Not Right' for Change to Lese Majeste Law: Politicians.” 29 April, online $<$ http://www.nationmultimedia.com/politics/Time-not-right-for-change-to-lese-majeste-law-poli30180926.html> (last accessed 9 March 2015).

Ockey, James (2004) "State, Bureaucracy, and Policy in Modern Thai Politics." 34 Journal of Contemporary Asia 143-62.

Prachatai news (2013) “Charter Court's Ruling Supports 'Tyrant Minority': Nitirat,” Prachatai (English site), 23 November, online <http://www.prachatai.com/english/node/3755> (last accessed 9 August 2015).

Prachatai news (2014) "Nitirat Member Worachet Pakeekut Detained by the Military," Prachatai (English site), 17 June, online <http://www.prachatai.com/english/node/4131> (last accessed 9 March 2015).

Reynolds, Frank (1978) "Religion and Rebellion: Thailand's Civic Religion and the Student Uprising of October 1973," in B.L. Smith, ed., Legitimation of Power in Thailand, Laos, and Burma, Chambersburg, PA: Anima.

Sarat, Austin, \& Stuart Scheingold (1998) "Cause Lawyering and the Reproduction of Professional Authority," in A. Sarat \& S. Scheingold, eds., Cause Lawyering: Political Commitments and Professional Responsibilities, New York: Oxford University Press, 3-28.

Sarat, Austin, \& Stuart Scheingold (2004) Something to Believe In: Politics, Professionalism, and Cause Lawyering, Stanford, CA: Stanford University Press.

Sarat, Austin, \& Stuart Scheingold (2006) "What Cause Lawyers Do For, and To, Social Movements: An Introduction," in A. Sarat \& S. Scheingold, eds, Cause Lawyers and Social Movements, Stanford: Stanford University Press, 1-34.

Saratee, Jarae (2014) "Human Rights Have No Color-Arnon Nampa," Kaosod Online, in Thai, June 18, online <http://www.khaosod.co.th/view_newsonline.php?newsid=TVRRd016QTJPVGM1 TIE9PQ $==>$ (last accessed 9 March 2015).

Stinchcombe, Arthur L. (2001) When Formality Works: Authority and Abstraction in Law and Organizations, Chicago: Chicago University Press.

Suwatee, Chamaipon (1989) บทบาทสถานภาพขององค์กรสิทธิมนุษยชน ในการเมือง ไทย: ศึกษากรณี สมาคมสิทธิเสรีภาพของประชาชน ["The Role of Human Rights Organizations in Thai Politics: A Case Study of the Union for Civil Liberties"], MA thesis, Thammasat University, Bangkok, in Thai.

Tejapira, Kasian (2001) Commodifying Marxism: The Formation of Modern Thai Radical Culture, 1927-1958, Melbourne: Trans Pacific Press.

Thompson, Edward P. (1976) Whigs and Hunters: The Origin of the Black Act, New York: Pantheon. Upham, Frank (2006) "Mythmaking in the Rule of Law Orthodoxy," in T. Carothers, ed., Promoting the Rule of Law Abroad: In Search of Knowledge, Washington, DC: Carnegie Foundation, 75-104.

Walker, Andrew (2012) Thailand's Political Peasants: Power in the Modern Rural Economy, Madison, WI: University of Wisconsin Press.

Weber, Max (1978) Economy and Society, Vol. II, Berkeley, CA: University of California Press. 